\title{
THE ABORIGINAL BIOGRAPHICAL INDEX IN THE LIBRARY OF THE AUSTRALIAN INSTITUTE OF ABORIGINAL AND TORRES STRAIT ISLANDER STUDIES: A RESEARCH AID
}

\author{
Ronda Wie
}

In 1982 Laurie Parkes and Diane Barwick announced the beginning of a national Aboriginal biographical register at the Australian Institute of Aboriginal Studies. ${ }^{1}$ The register (to become known later as the Aboriginal Biographical Index) was intended to be an important record of the achievements of Aboriginal and Torres Strait Islander people, and a much needed resource for family and community history research. In 1982 the Index comprised 1,100 card entries recording biographical information about individuals and families.

The Index was established in the Library by Laurie Parkes and Diane Barwick, with special funding by the Institute's Council. Its development was continued by Diane Barwick whose systematic searches of the Library's resources resulted in a total of 12,000 card entries in the Index by the time of her death in 1986. With further support from Council, work on the Index was continued by Diane Smith who, in 1990, reported to Council that the Index held 20,164 records of biographical information relating to 14,392 people. By December, 1992, there were more than 31,000 entries on cards and a computer database, relating to approximately 21,000 individuals and families.

The Aboriginal Biographical Index includes biographical information extracted from published sources within the Library. Owing to the extent of this information, only a very small proportion of sources has been searched and indexed to date. Work has focused on publications of greatest biographical interest, particularly reports by government administrators of Aboriginal affairs, and magazines published by such bodies as the NSW Aborigines Welfare Board and church missions. Such publications contain a wealth of information that is not easy to access without some knd of index of names. They also belong to a period in Australian history that witnessed the taking of children from their parents and families - the very people who are now using the Index to further their family history research.

In 1991 the Council of the Australian Institute of Aboriginal and Torres Strait Islander Studies agreed to a proposal that the current researcher give high priority to the integration of biographical information held in the Library's special collections of films, audiotapes and pictures. My work in $1992 / 93$ is to begin this process with the Pictorial Collection, using my experience as acting curator of the Collection in 1991.

Between April and December 1992, just over one quarter of the biographical information stored in the Pictorial Collection was transferred to the Aboriginal Biographical Index by systematic examination of each photographic collection within the Pictorial Library. Non-restricted biographical information is extracted from caption lists accompanying the collections and is transferred directly onto the Index's database. This central point of access to the Library's resources has streamlined biographical searches considerably.

Ronda Wie was the Aboriginal Biographical Index research officer in the Library of the Australian Institute of Aboriginal and Torres Strait Islander Studies until June 1993. She now lives in Darwin.

$1 \quad$ Parkes \& Barwick 1982. 
The Aboriginal Biographical Index is heavily used by a range of researchers including AIATSIS staff (particularly in relation to the forthcoming Encyclopedia of Aboriginal and Torres Strait Islander Australia), family history researchers and authors. Recently the ACT Department of Land, Environment and Planning searched the Index for names of prominent Aboriginal and Torres Strait Islander people before assigning street names to two new suburbs in Canberra. Requests for information also come through organisations acting on behalf of individuals, such as Link-Up, the education unit at Goulburn Gaol and various offices of the Aboriginal and Torres Strait Islander Commission.

As well as requesting information by telephone or mail, researchers are welcome to visit the Library to use the card Index themselves or obtain a printout from an online search of the database. Many family history researchers use the Index as the first step in their search. They may then be directed to other organisations, such as church or government archives, and advised on how to apply for access to these records.

Other aids to researchers have resulted from work for the Index. Thesauri of personal and community names have been maintained to include variations in spelling and changes in choice of names over time. A geographic register lists information sources for local areas. These may be titles of publications, such as Land Rights News (NT) or Torres Strait Islander Monthly, or names and addresses of local organisations.

It is hoped that continued funding will support expansion of the Aboriginal Biographical Index to incorporate other sources of accessible, non-restricted biographical information in the AIATSIS Library. Because of Australia's history over the past two hundred years, Aboriginal and Torres Strait Islander people from all over the country will always be searching for their family histories. The Aboriginal Biographical Index has already been found to be invaluable through its centralisation and integration of biographical information from all the states and territories in supporting that search.

\section{REFERENCE}

Parkes, Laurie \& Barwick, Diane 1982, 'Beginning a natonal Aboriginal biographical register at the Australian Institute of Aboriginal Studies', Aboriginal History, vol. 6, no. 2, pp. 135-39. 